\title{
A BRIEF HISTORY OF THE POSTGRADUATE MEDICAL SCHOOL
}

by

\section{CHARLES NEWMAN}

The existence of the Postgraduate Medical School depends, more than that of most schools, on an historical setting. At the end of the nineteenth century, for reasons which I shall not go into now, there came to be a demand for postgraduate education in England. It was started in 1888 by Charles Keetley, a surgeon at the West London Hospital, one of the earliest followers of Lister. It was developed and maintained by Leonard Bidwell, a pioneer abdominal surgeon with an interest in dermatology. He was not such a colourful character, but had great persistence and enthusiasm and, as Dean, established the Postgraduate College.

In 1898 three more postgraduate institutions were started: The London Postgraduate Association, the Secretary of which was Dr. Raymond Crawfurd, subsequently Registrar of the College of Physicians; The Medical Graduate College and Polyclinic, which was founded by the great Sir Jonathan Hutchinson, another surgeon with an interest in dermatology and, indeed, an interest in practically everything (he was known in his time as the 'Universal Specialist'); and, thirdly, The North East London Postgraduate College, which was based on a hospital. All these organizations were successful for a time, but they failed in the end, probably because they were all teaching the medicine of the past, and not the medicine of the next generation, which was going to be in vogue thirty years later. The real need was for what Starling called 'academic medicine'. He described this to the Haldane Commission in well known, if ungrammatical, words: he said 'This is what I regard as the University spirit, not simply diagnosing a patient and deciding what we do for him in order to earn our fee, but what we can get out of this case in order to do better next time. How we can get some knowledge out of this patient in order to have more power when we have another man in the same condition'. This same thing was practically interpreted by Osler in the form of 'Hospital Units'. What he said to the Haldane Commission was: 'Just as professors of chemistry need a laboratory and assistants, so a professor of medicine needs a Hospital Unit of beds, laboratories and assistantsto enable him to treat, to teach and to research'. He got this idea from Welch at Johns Hopkins, and Welch got it from Kohnheim, and it ultimately stemmed from von Humboldt, as part of the redevelopment of the academic idea in German Universities.

Haldane needed little conviction, because he also had a great admiration for the German academic system, and he put the idea across very strongly in the final report of his Commission. It had little impact at the moment because it coincided with the Kaiser's War, which rather diverted people's attention. But at the end of the war the matter was taken up again. Osler saw that a great opportunity was going to be presented for England to take the place of Vienna, which had hitherto been the Mecca of postgraduate medical students. He said in 1918 that 'The profession must get 


\section{News, Notes and Queries}

over its infantile fears of government finances, and must start to think about postgraduate education on an imperial scale'. This was a great vision, and Osler enshrined it in the foundation of the Fellowship of Medicine. Unfortunately he died in December 1919, and the Fellowship of Medicine developed on other lines. But just before Osler died, a stand was taken by a number of people. Sir Clifford Allbutt, the Regius Professor of Physic at Cambridge, said that 'All previous attempts at postgraduate education in this country had failed, and must fail, unless they were rooted in the laboratory and the ward' and he, with Osler and Meakins, President of the Royal College of Surgeons, and Sir Bertrand Dawson and others urged that a hospital should be taken over for the purposes of postgraduate education alone. All this stimulated Lord Addison, the Minister of Health, who appointed a committee under the Earl of Athlone in 1921 to look into the question.

The Athlone Committee reported very quickly that there should be a school attached to a hospital devoted solely to postgraduate medical education (a school of the university), that there should be a central office to co-ordinate and develop all postgraduate education in London and that an Institute of State Medicine should be established, which ultimately became the London School of Hygiene and Tropical Medicine.

In 1925 Neville Chamberlain, who was then Minister of Health, appointed and presided over a committee which looked into practical details of how the Postgraduate School could be brought about. They asked all the undergraduate hospitals in London whether they would undertake the venture, and they all turned it down 'out of hand' except St. Bartholomew's, which only turned it down after considerable thought. So they fixed on the West London Hospital. Neville Chamberlain wrote to them on 7 March 1927 definitely offering them the task of being the centre of the imperial organization for postgraduate education in London.

At the same time, Dr. Frederick Menzies, the Principal Medical Officer to the London County Council, knew that the new Local Government Act was going to put all the municipal hospitals under the County Council's control. He had a wonderful vision: he foresaw the possibility of what was neither more nor less than a Regional Hospital Scheme for the whole of the west of London. In the same year he wrote to the West London Hospital suggesting that all the hospitals in west London should be put under their control, unifying eight special hospitals, four general hospitals (including the one in DuCane Road), and five dispensaries, providing in all 2,000 beds for postgraduate medical education. The West London staff agreed at once, in principle, to both these suggestions, but nothing more was heard of the scheme. There was a change of Government: Arthur Greenwood became Minister of Health. The new Government decided, probably quite rightly, in view of the size of the West London site, on DuCane Road as the hospital to be chosen. It may have been the right decision, but it must have seemed terribly unfair to the West London Hospital.

Hammersmith Hospital was originally the Workhouse Infirmary and Workhouse of the Hammersmith Board of Guardians. For its time it was a pretty palatial hospital: it was known, as a matter of fact, as the 'Paupers' Paradise' and the 'Ne Plus Ultra' and its extravagance was the subject of an inquiry by the Board of Trade. It was 


\section{News, Notes and Queries}

built in 1904. It was taken over in the 1914 war and became Sir Robert Jones' 'Military Orthopaedic Hospital', where the development of modern artificial limbs took place. They were made in a hut, which was taken over by the Postgraduate School later on as its refectory. The Military Orthopaedic Hospital continued until 1925 when it was transferred to St. Mary's, Roehampton, where it still is. Hammersmith Hospital reverted to the Board of Guardians and a photograph survives of the complete medical staff of the hospital as it was in 1931, consisting of the medical superintendent and four assistants-a staff now represented by about 140 persons.

To return to the School, the London County Council and the Treasury agreed each to provide $£ 250,000$ towards building the School and bringing the Hospital to a standard suitable as a teaching hospital. In 1931 the Charter was given by the King, and shortly after that financial disaster overtook the whole plan in the form of the great financial crisis. The Treasury and the London County Council decided that the whole scheme would have to be abandoned. Frederick Menzies, who, with Lord Dawson, was desperately keen on getting the School started, saw that unless something was done then, nothing would be done in his lifetime, and how right he was. So he asked his Treasurer at County Hall, Sir Angus Scott, if the London County Council would put up only $£ 100,000$ if the Treasury put up another $£ 100,000$ ? Angus Scott, knowing perfectly well that it was out of the question, agreed. Menzies then went round to see Neville Chamberlain and, in his own words, 'practised an innocent deception' on him, by repeating the request without mentioning that he had already seen Sir Angus Scott. Neville Chamberlain also agreed. When Menzies put the two notes, he had got them to write, before Angus Scott, again using Menzies' words 'Scott called him every name he could think of and said "Go ahead: you shall have your money, and you deserve it!",

The Foundation Stone was laid in 1933 , and the $£ 100,000$ on each side was devoted to building a token School, an outpatient department and a new surgical block.

The School was opened in 1935, with Francis Fraser as Professor of Medicine and Kettle as Professor of Pathology. Both came from St. Bartholomew's, and were both completely imbued with academic medicine, and they started the School exactly on the lines laid down by Starling and Osler. The first Professor of Surgery, Grey Turner, and the first Professor of Obstetrics, James Young, followed the lines laid down by Kettle and Fraser, and the School has developed on academic lines ever since. It was organized as four departments: general medicine, general surgery, general pathology, and obstetrics and gynaecology, each under the direction of a professor, with a reader, four assistants and a few part-time specialist consultants. The assistants were paid $£ 300$ per annum.

Before the war, part of the School's activity was concerned with providing refresher courses for general practitioners. This, together with a clientele mainly derived from the services and from abroad, made the School a success from the beginning. The School was in serious need of additional buildings by 1938, but the war put a stop to all idea of further building.

The School continued throughout the war. It ran seventy-two special war courses in which the lecturers were, for the most part, serving officers, and these courses were attended by 3,700 officers from British, American, Canadian and other forces, 
and this had a considerable effect in spreading the School's reputation abroad, because the officers attending saw the quality of the research work in progress.

After the war, the School gave up its position as an independent school of the university in order to make possible the start of the Postgraduate Medical Federation, which brought into union all the postgraduate teaching activities in London. The Federation took over the provision of refresher courses for general practitioners, and the School was able to concentrate on its work as a training ground for consultants and teachers.

The School has usually been short of money. For years every penny went to the development of research, a policy which paid dividends, though the University Grants Committee did eventually complain about the lack of amenities for the postgraduate doctors. It has always been short of space: the Medical Research Council thought well enough of the School to build and develop on the site. Help came from Aneurin Bevan, who gave a licence for eight huts at a time when building licences were unobtainable. Extra accommodation was added by the hospital, and laboratories were built on existing buildings. The School finally started its own appeal for building in 1956. Mr. W. W. Watt, Lord Stamp, and others carried this through with success. The Wolfson Foundation gave the money for the building to house the amenities, where large medical societies can meet and the School collected over $£ 1,000,000$ for the new thirteen-storey building for the rest of the School going up. The progress of the School has just about fitted rightly with Hughlings Jackson's famous remark that 'It takes twenty years to get an idea out of the head of the medical profession, and another twenty years to get a new one in'. It took about twenty years, 1921-1941, to get the old idea of postgraduate education out of people's minds, and between 1941 and 1961 the School has gradually achieved a certain status in this country, as well as abroad. 